\title{
INVENTARISASI MANAJEMEN ASET BERBASIS ONLINE PADA PD.BPR KERTA RAHARJA CABANG BALARAJA
}

\author{
Fauzan Manafi Albar ${ }^{1}$ \\ Sri Hardiyanti ${ }^{2}$ \\ Kiky Rizky Amelia Ramadhona ${ }^{3}$ \\ Dosen STMIK Raharja ${ }^{1}$ \\ STMIK Raharja Jurusan Sistem Informasi ${ }^{2,3}$ \\ Jl. Jendral Sudirman No. 40, Modernland, Tangerang \\ E-mail : kiky.rizky@ @raharja.info ${ }^{1}, \underline{\text { sri.hardiyanti@ raharja.info }}{ }^{2}$, $\underline{\text { fauzan.manafi@ raharja.info }}^{3}$
}

\begin{abstract}
ABSTRAK
Setiap perusahaan membutuhkan informasi yang cepat dan akurat, salah satunya adalah informasi mengenai aset yang dimiliki oleh suatu perusahaan. Aset merupakan barang atau benda yang terdiri dari benda yang bersifat bergerak dan benda yang bersifat tidak bergerak yang dimiliki oleh perusahaan. PD. BPR Kerta Raharja merupakan Perusahaan Daerah milik Pemerintah Kabupaten Tangerang bersamasama Pemerintah Provinsi Banten, Provinsi Jawa Barat dan PT Bank Jabar Banten yang bergerak dalam pemberian kredit pada masyarakat. Yang dimana saat ini dalam proses pencatatan data aset masih menggunakan aplikasi Ms. Excel, dimana masih dapat terjadi salah input data aset dan bisa saja data hilang dari penyimpanan. Tujuan penelitian ini adalah untuk melakukan analisa pada sistem yang berjalan untuk mengetahui penerapan sistem informasi manajemen aset pada PD. BPR Kerta Raharja Cabang Balaraja. Penelitian dilakukan dengan cara observasi, wawancara, dan studi pustaka. Analisanya menggunakan metode SWOT Analysis (Strenghts, Weaknesses, Opportunities, Threats). kemudian menggunakan UML (Unified Modeling Language) untuk menggambarkan prosedur sistem yang berjalan. Hasil dari penelitian ini berupa rekomendasi dan saran pengembangan sistem informasi sesuai dengan kebutuhan user yang tertuang dalam elisitasi.
\end{abstract}

Kata Kunci : Manajemen Aset, data aset, analisis

\begin{abstract}
Every company needs fast and accurate information, one of which is information about assets owned by a company. Assets are goods or objects consisting of movable and immovable property owned by the enterprise. PD. BPR Kerta Raharja is a Regional Company owned by the Government of Tangerang Regency together with the Provincial Government of Banten, West Java Province and PT Bank Jabar Banten engaged in lending. Which is currently in the process of recording data assets are still using the Ms. application Excel, the data has not been database and not yet integrated, where there can still be wrong input of asset data and data may be lost from storage. The purpose of this study is to perform analysis on the running system to determine the implementation of asset management information systems in PD. BPR Kerta Raharja. Research is done by observation, interview, and literature study. The analysis used SWOT Analysis Method (Strengts, Weaknesses, Opportunities, Threats). Then use UML (Unified Modeling Language) to describe the running system procedure. The result of this research is recommendation and suggestion of information system development according to user requirement as stated in ellicitation.
\end{abstract}

Keywords: Asset Management, asset data, analysis 


\section{PENDAHULUAN}

Di masa yang serba cepat ini, penggunaan komputer dan sistem-sistemnya sudah menjadi kebutuhan yang utama dalam rangka meningkatkan kinerja suatu instansi atau perusahaan. Setiap proses semi kompoter dari instansi atau perusahaan tersebut dapat digantikan dengan sistem yang terkomputerisasi karena penyediaan informasi yang lebih canggih serta dapat mendukung proses pengambilan keputusan yang dilakukan oleh manajemen.

Namun pada kenyataanya masih banyak instansi atau perusahaan yang menggunakan sistem yang belum terkomputerisasi dengan baik, sama halnya yang terjadi di Perusahaan Daerah Bank Pengkreditan Rakyat (PD. BPR) Kerta Raharja Cabang Balaraja. PD. BPR Kerta Raharja merupakan Perusahaan Daerah milik Pemerintah Kabupaten Tangerang bersama-sama Pemerintah Provinsi Banten, Provinsi Jawa Barat dan PT Bank Jabar Banten yang bergerak dalam pemberian kredit pada masyarakat. Dalam kegiatan membuat laporan manajemen data aset saat ini, PD. BPR Kerta Raharja Cabang Balaraja belum memiliki sistem yang terintegrasi dalam pengelolaan manajemen data aset, pengelolaan masih menggunakan aplikasi dekstop yang dioperasikan oleh satu komputer dengan menggunakan aplikasi Ms. Excel. Data-data yang ada dikelola dalam bentuk arsip-arsip, sehingga relatif lambat untuk melalukan koreksi dan pengawasan terhadap data aset.Dan bisa menimbulkan kendala dalam kepraktisan dan efisiensi dalam hal pengecekan. Dengan menggunakan sistem aplikasi, semua dapat dilakukan dengan proses yang mudah dan cepat serta lebih efektif dan efisien karena dengan menggunakan sistem aplikasi semua proses akan berjalan sangat cepat dan data yang tersimpan akan aman. Berdasarkan penjelasan tersebut, maka tujuan yang ingin dicapai oleh peneliti dalam pelaksanaan penelitian ini untuk mengetahui implementasi sistem menajement data aset pada PD.BPR Kerta Raharja.

\section{METODE PENELITIAN}

Metode penelitian yang dilakukan dalam penelitian ini adalah mengumpulkan data mengenai keadaan secara langsung, dan melakukan analisa terhadap keadaan tersebut guna mendapatkan suatu hasil akhir yang bermanfaat bagi penelitian. Teknik pegumpulan data yang digunakan untuk mencari atau mengumpulkan data serta mengolah informasi yang diperlukan yaitu metode observasi, wawancara dan studi pustaka.Teknik analisa menggunakan metode analisa SWOT.

\section{LANDASAN TEORI}

\section{Definisi Manajemen}

Menurut Husain Usman (2013:6), “ Manajemen adalah Serangkaian kegiatan yang diarahkan langsung penggunaan sumber daya organisasi secara efektif dan efisien dalam rangka mencapai tujuan organisasi. Secara universal manajemen adalah penggunaan sumberdaya organisasi untuk mencapai sasaran dan kinerja yang tinggi dalam berbagai tipe organisasi profit maupun non profit".

\section{Definisi Aset}

Aset atau aktiva dalam akuntansi memiliki pengertian sebagai sumber daya atau kekayaan yang dimiliki oleh suatu entitas. Aset tersebut diperoleh dari peristiwa di masa lalu dan diharapkan akan memberikan manfaat di masa yang akan datang. 


\section{Definisi Manajemen Aset}

Menurut Dr. A Gima Sugiama (2013:15),"Manajemen aset adalah ilmu dan seni untuk memandu pengelolaan kekayaan yang mencakup proses merencanakan kebutuhan aset ,mendapatkan, menginventarisasi, melakukan legal audit, menilai, mengoperasikan, memelihara, membaharukan atau menghapuskan hingga mengalihkan aset secara efektif dan efisien".

\section{Definisi UML}

Menurut Rosa dan Sholahuddin (2013:13), "Unified Modeling Language (UML) adalah salah standar bahasa yang banyak digunakan didunia industri untuk mendefinisikan requirment, membuat analisa \& desain, serta menggambarkan arsitektur dalam pemograman berorientasi objek".

\section{Definisi MSQL}

Menurut Sibero (2011:97), berpendapat bahwa "MySqL atau dibaca "My Sekuel” adalah suatu RDBMS (Relational Data-base Management System) yaitu aplikasi sistem yang menjalankan fungsi pengolahan data".

Menurut Raharjo (2011:21), berpendapat bahwa "MySQL adalah RDBMS atau server database yang mengelola database dengan cepat menampung dalam jumlah sangat besar dan dapat di akses oleh banyak user".

Berdasarkan pendapat yang dikemukakan di atas dapat ditarik kesimpulan bahwa MySQL adalah suatu software atau program yang bersifat open source yang digunakan untuk membuat sebuah database serta menjalankan fungsi sebagai pengolah data.

\section{Definisi Database}

Raharjo (2011:3) berpendapat, "Database adalah kumpulan data yang terintegrasi dan diatur sedemikian rupa sehingga data tersebut dapat dimanipulasi, diambil, dan dicari secara cepat".

\section{PERMASALAHAN}

Melihat perkembangan teknologi yang semakin cepat dapat mendukung proses pengambilan keputusan yang dilakukan oleh manajemen. Perkembanganinformasi yang lengkap dan akurat akan memberikan kepastian dan menghindarkan keraguan akan informasi tersebut serta keabsahan dari informasi tersebut. Namun di Perusahaan Daerah Bank Pengkreditan Rakyat (PD. BPR) Kerta Raharja Cabang Balaraja masih terdapat beberapa masalah yang dihadapi terutama segala kegiatan operasional.Dalam hal ini terdapat permasalahan pada sistem manajemen aset yang berjalan di PD. BPR Kerta Raharja Cabang Balaraja yang masih belum terkomputerisasi, dimana proses pembuatan laporannya terdiri dari inventaris aset, neraca, laba rugi, evaluasi, komulatif dan rincian-rincian yang digabung menjadi satu file dan beberapa worksheet sehingga data belum terdatabase dan belum terintegrasi sehingga masih dapat terjadi salah input data aset dan bisa saja data hilang dari penyimpanan. 


\section{LITERATURE REVIEW}

Sebelumnya terdapat banyak penelitian yang dilakukan mengenai management aset dalam upaya meningkatkan manajemen yang baik dan memudahkan dalam proses pengolahan dan pembuatan laporan data aset, dilakukan studi pustaka sebagai salah satu alat dari penerapan metode penelitian. Diantaranya mengidentifikasi kesenjangan, mengidentifikasi metode yang pernah dilakukan serta mengetahui orang lain yang spesialisasi dan era penelitiannya sama dibidang ini. Beberapa literature review tersebut adalah sebagai berikut :

1. Penelitian yang dilakukan oleh Remon Afandi Junior Simbolon pada tahun 2017 dengan judul "Perancangan Sistem Informasi Inventarisasi Aset Tetap pada PT Tirta Nusa Indotama Tangerang”.Metode perancangan menggunakan UML (Unified Modeling Language), bahasa pemrograman PHP, menggunakan database MySQL, Adobe Dreamweaver CS5 untuk mendesign web yang akan dibuat dan melakukan serangkaian pengujian sistem menggunakan metode black box testing agar bagian yang masih bermasalah dapat segera diperbaiki. Hasil akhir yang dicapai pengolahan laporan akan berjalan secara maksimal dimana staff general affair dan accounting akan bekerja sama secara mudah dalam mengelola aset yang telah ada dan aset yang akan datang.

2. Penelitian yang dilakukan oleh Elmi Fauziati pada tahun 2016 dengan judul "Perancangan Sistem Infromasi Manajemen Aset Di Kecamatan Pasar Kemis". Metode perancangan menggunakan UML (Unified Modeling Language), bahasa pemrograman ASP VisualBasic Script, IIS (Internet Information Services) tool yaitu paket perangkat lunak ke dalam satu buah paket, database untuk SQLServer, Adobe Dreamweaver CS5 untuk mendesign web yang akan dibuat. Hasil akhir yang dicapai pada sistem informasi manajemen aset mempunyai kelebihan dalam membantu user untuk memperoleh informasi lebih cepat, tepat dan akurat mulai dari pendataan sampai pembuatan laporan.

3. Penelitian yang dilakukan oleh Rika Yunitarini pada tahun 2014 dengan judul "Sistem Informasi Manajemen Tata Kelola Aset Informasi Perhotelan pada Hotel Mahkota Lamongan". Sistem Informasi Hotel Mahkota yang dibuat menggunakan Microsoft Visual Basic sebagai bahasa pemrograman serta menggunakan database SQL server. Hasil Akhir Sistem informasi ini memiliki beberapa fitur yang dapat memudahkan aktifitas pengelolaan informasi di hotel Mahkota, antara lain aktifitas front office dan back office. Dengan adanya sistem ini, diharapkan mampu meningkatkan manajemen yang baik, sehingga tercipta hotel dengan pelayanan yang lebih baik.

4. Penelitian yang dilakukan oleh Gentisya Tri Mardiani pada tahun 2013 dengan judul "Sistem Monitoring Data Aset dan Inventaris PT Telkom Cianjur Berbasis Web". Sistem Monitoring ini berbasis web, menggunakan bahasa pemrograman PHP dan Local Area Network (LAN) dan Desktop Support. Hasil akhir dengan aplikasi ini memudahkan dalam proses pengolahan dan pembuatan laporan data aset dan pengolahan distribusi perangkat kepada karywan, serta aplikasi mampu mengurangi kemungkinan adanya duplikasi data.

\section{PEMBAHASAN}

Setelah mengamati dan meneliti dari beberapa permasalahan yang terjadi berdasarkan sistem yang berjalan di PD. BPR Kerta Raharja Cabang Balaraja,sehingga untuk mengatasi berbagai masalah yang dihadapi yaiu diantaranya diperlukan proses manajemen aset yang dilakukan berupa sistem web, untuk mempermudah input data, mengetahui keseluruhan jumlah 
aset serta mengetahui jangka waktu penyusutan aset dan pembuatan laporan, diperlukan sistem yang akan mempermudah dalam proses pengelolaan data serta update data aset yang terbaru yang berfungsi untuk memperbaiki kekurangan sistem yang berjalan serta dapat memberikan informasi yang cepat dan akurat sehingga informasi tersebut dapat berguna untuk perusahaan.

Analisis SWOT dilakukanuntuk mencari strategi dengan menggunakan kekuatan (strenghts), peluang (opportunities), kelemahan (weakness) dan ancaman (threats) (SWOT). Dengan mengidentifikasi kekuatan dan faktor-faktor positif yang berasal dari internal organisasi (strenghts), kelemahan dan faktor-faktor negatif dari internal (weakness), peluang atau kesempatan dan keuntungan dari faktor eksternal (opportunities) dan ancaman atau resiko yang dipengaruhi oleh faktor eksternal organisasi (threats).

Tabel 1 Faktor Strategi Internal PD. BPR Kerta Raharja Cabang Balaraja

\begin{tabular}{|c|l|l|}
\hline \multicolumn{3}{|c|}{ Faktor Strategi Internal } \\
\hline No & \multicolumn{1}{|c|}{ Strengths } & \multicolumn{1}{c|}{ Weakness } \\
\hline 1 & $\begin{array}{l}\text { SDM di PD. BPR Kerta Raharja } \\
\text { memiliki kompetensi dasar kualifikasi di } \\
\text { bidang komputer dan telekomunikasi } \\
\text { yang cukup. }\end{array}$ & $\begin{array}{l}\text { Pengolahan dan } \\
\text { penyimpanan data aset } \\
\text { masih berupa software } \\
\text { Ms. Excel. }\end{array}$ \\
\hline \multirow{2}{*}{3} & $\begin{array}{l}\text { Sarana dan prasarana penunjang } \\
\text { komunikasi dan informasi komputer } \\
\text { jaringan, akses internet, email dan } \\
\text { printer. }\end{array}$ & $\begin{array}{l}\text { Belum terintegrasinya } \\
\text { sistem yang dimiliki } \\
\text { perusahaan unuk } \\
\text { pengelolaan sumber daya } \\
\text { yang ada. }\end{array}$ \\
\hline \multirow{2}{*}{$\begin{array}{l}\text { Perusahaan daerah dengan kualitas yang } \\
\text { baik di bidang pengkreditan dan dengan } \\
\text { pelayanan kepuasan nasabah. }\end{array}$} & $\begin{array}{l}\text { Belum optimalnya } \\
\text { penggunaan sumber daya } \\
\text { yang ada. }\end{array}$ \\
\hline
\end{tabular}

Tabel 2 Faktor Strategi Eksternal PD. BPR Kerta Raharja Cabang Balaraja

\begin{tabular}{|c|l|l|}
\hline \multicolumn{3}{|c|}{ Faktor Strategi Eksternal } \\
\hline No & \multicolumn{1}{|c|}{ Opportunities } & \multicolumn{1}{c|}{ Threats } \\
\hline 1 & $\begin{array}{l}\text { Semakin berkembangnya perusahaan } \\
\text { semakin bertambah pula aset yang ada, } \\
\text { sehingga proses pelaporan aset dapat } \\
\text { diproses dengan mudah. }\end{array}$ & $\begin{array}{l}\text { Gangguan pada komputer } \\
\text { seperti jaringan maupun } \\
\text { gangguan LAN/WAN } \\
\text { yang tidak berfungsi. }\end{array}$ \\
\hline 2 & $\begin{array}{l}\text { Perkembangan di bidang teknologi } \\
\text { informasi dan komikasi yang cukup pesat. }\end{array}$ & $\begin{array}{l}\text { Ancaman virus, spyware, } \\
\text { malware dan cracker } \\
\text { yang dpat membuat } \\
\text { kinerja sistem rusak. }\end{array}$ \\
\hline 3 & $\begin{array}{l}\text { Pelayanan terhadap nasabah perusahaan } \\
\text { memiliki nilai kepuasan yang maksimal. }\end{array}$ & $\begin{array}{l}\text { Adanya persaingan } \\
\text { dengan perusaan- } \\
\text { perusahaan di bidang } \\
\text { pengkreditan lainnya. }\end{array}$ \\
\hline
\end{tabular}


Alur proses yang digunakan dalam menjalankan sistem manajemen aset pada PD. BPR Kerta Raharja Cabang Balaraja :

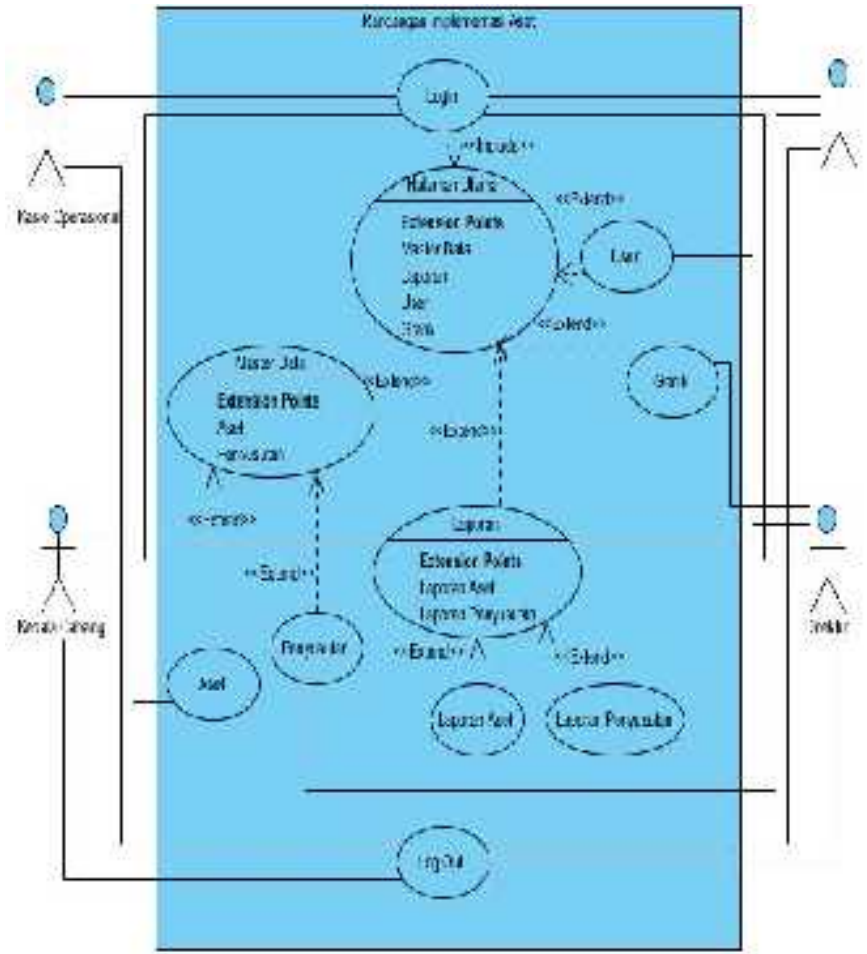

\section{Gambar 1 Use Case Diagram Sistem Manajemen Aset yang berjalan}

Berdasarkan gambar 1. Use case diagram yang sedang berjalan saat ini dapat dijelaskan bahwa:

1. Satu sistem yang menjelaskan seluruh kegiatan yang sedang berjalan.

2. Empat actor, yaitu Kasie. Operasional, Accounting, Kepala Cabang dan Direktur.

3. Enam use case yaitu, pengadaan aset, input harga pembelian, penginputan data penyusutan, membuat laporan, menyetujui laporan dan menyerahkan laporan.

\section{IMPLEMENTASI}

Dibuat perancangan sistem aplikasi web ini merupakan alat bantu untuk memudahkan user untuk mengakses data aset agar sistem efektif dan efisien pada PD. BPR Kerta Raharja Cabang Balaraja. 
1. Tampilan Login
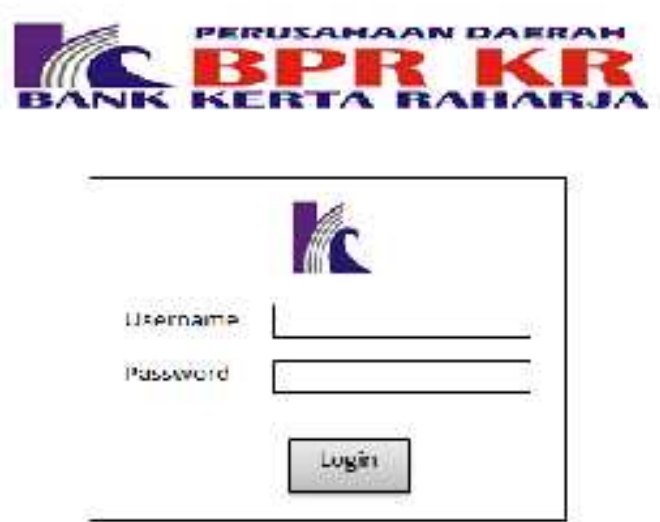

Gambar 2. Tampilan Login

Tampilan login ini digunakan beberapa level user untuk mengakses masuk halaman pertama.

2. Tampilan halaman utama

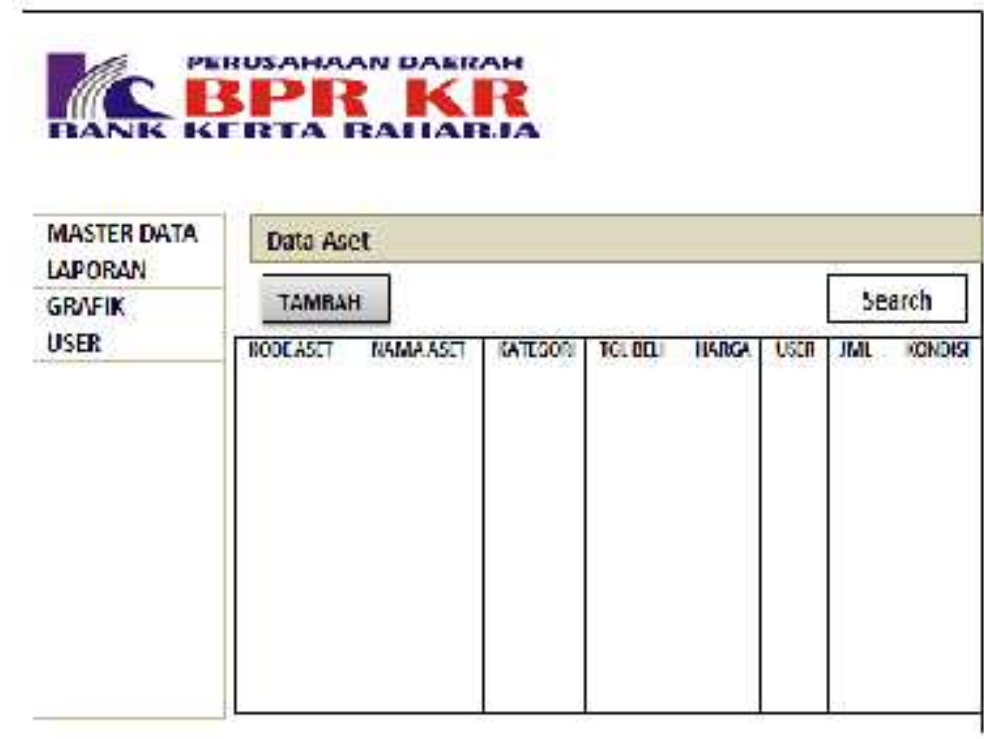

\section{Gambar 3. Tampilan Halaman Utama}

Tampilan Halaman Utama berisi tampilan profil user yang mengakses dan beberapa ikon menu seperti master data, laporan, grafik, dan user. 
3. Tampilan menu aset

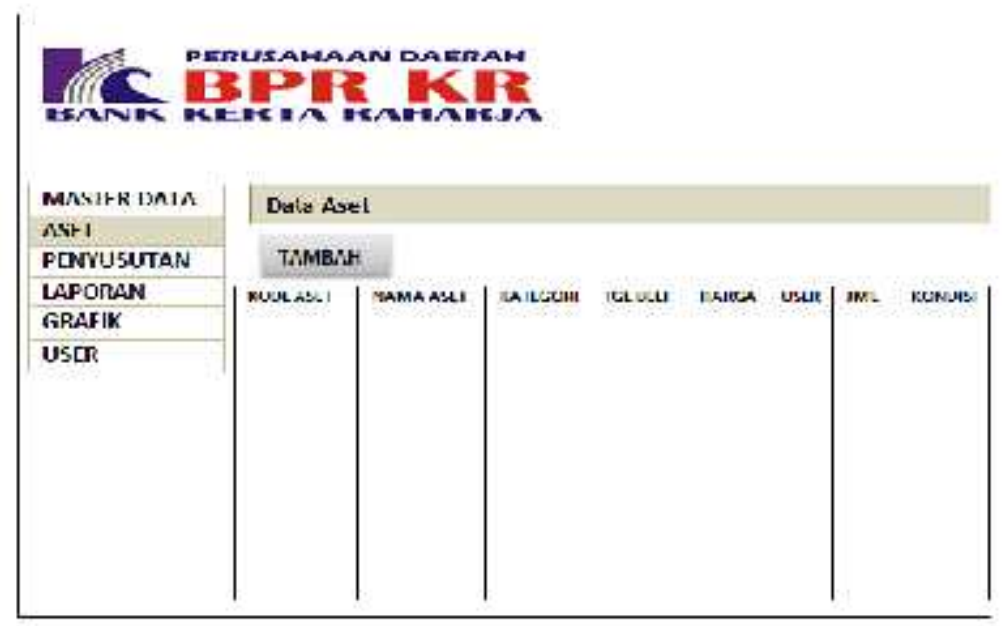

Gambar 4. Tampilan Menu Aset

Tampilan Menu Asetyang terdapat di master data ini berisi tampilan kode aset, nama aset, kelompok, tanggal beli, harga, user, jumlah, lokasi dan kondisi.

4. Tampilan input aset

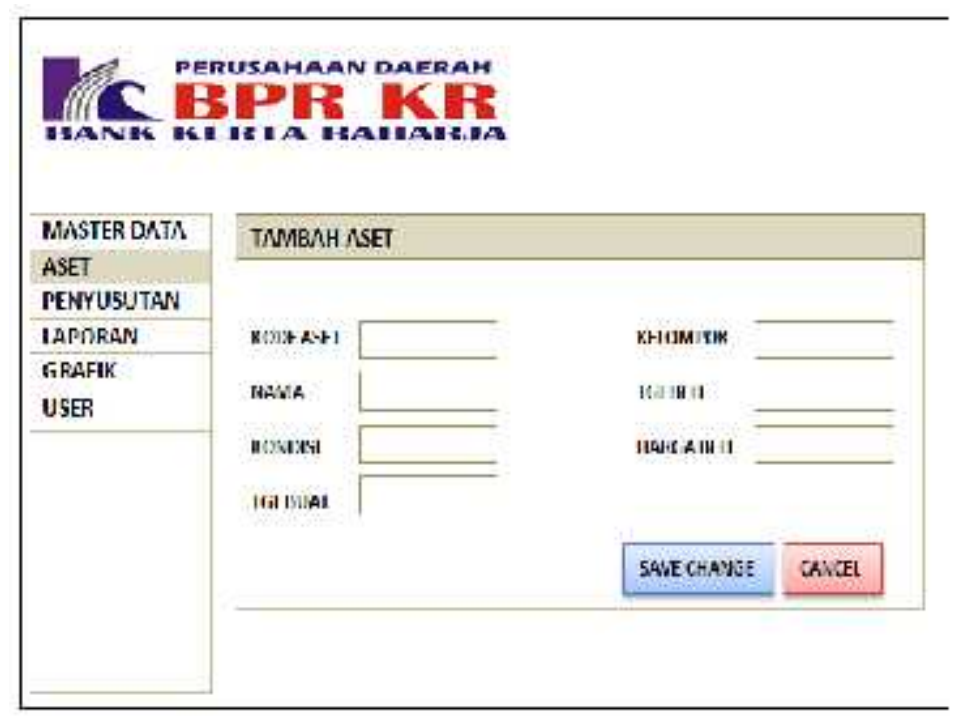

Gambar 5. Tampilan Input Aset

Tampilan Input Asetyang terdapat ini berisi tampilan penginputan data aset yang akan dilakukan oleh accountig. 
5. Tampilan input penyusutan

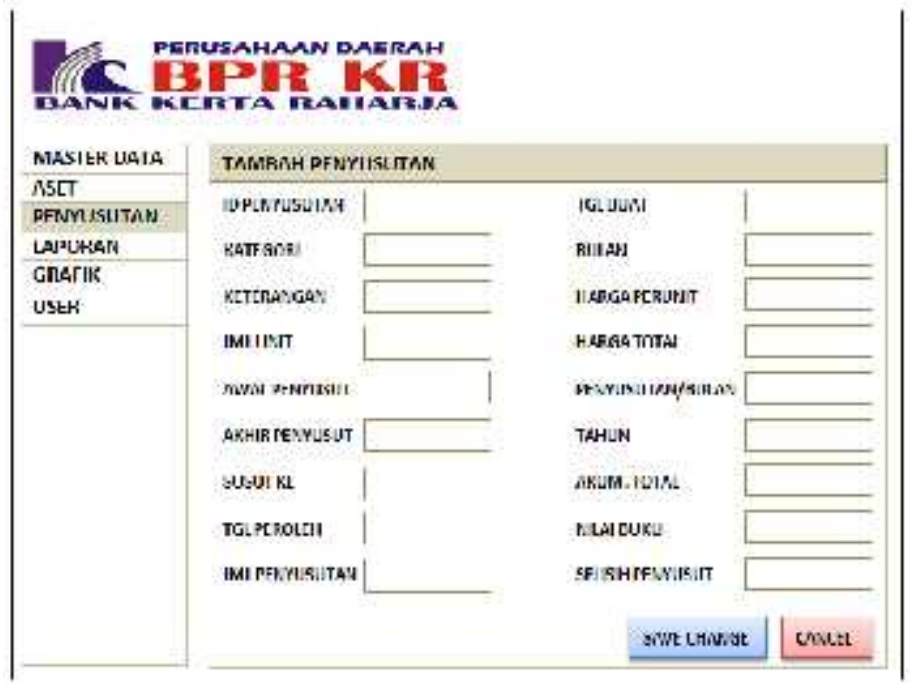

\section{Gambar 6. Tampilan Input Penyusutan}

Tampilan Input Penyusutan ini berisi tampilan penginputan data penyusutan yang akan dilakukan oleh accounting.

6. Tampilan laporan aset

\begin{tabular}{|c|c|c|c|c|c|c|c|}
\hline 10 & kat: & MEETbisi & MATjil & 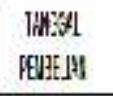 & An: & $\| \mathscr{R}$ & 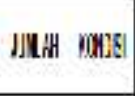 \\
\hline ' & bi & bote $b^{2}=4$ & 4atsis & Bbas:60 & "rives & is & EAl. \\
\hline 2 & \% & hod his is & $48 \mathrm{~s}$ & 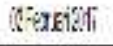 & sitoes? & \& & Ehe \\
\hline
\end{tabular}

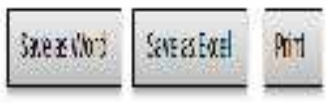

Gambar 7. Tampilan Laporan Aset

Tampilan Laporan Aset ini berisi tampilan jumlah kelompok aset dan jumlah proses yang dapat mencari laporan lengkapnya di tombol cari laporan.

7. Tampilan laporan penyusutan

\begin{tabular}{|c|c|c|c|c|c|c|c|c|c|c|c|}
\hline \multirow{2}{*}{$\because$} & \multirow{2}{*}{$\pi$} & \multirow{2}{*}{ T:4> } & \multirow{2}{*}{ जr: } & \multirow{2}{*}{$\begin{array}{l}\text { Pris. } \\
\text { Hell.ti }\end{array}$} & \multirow{2}{*}{ HX! } & \multirow{2}{*}{ IIt } & \multicolumn{2}{|c|}{ Irsid } & \multicolumn{2}{|c|}{ 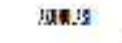 } & \multirow{2}{*}{ arg } \\
\hline & & & & & & & We! & H. & $1: 3$ & 0.4 & \\
\hline . & $\forall$ & 6...6 & $+5 . . J$ & Wait:E & $B x$ & & 8 & $3 x:$ & B & KE & X: \\
\hline ? & $\%$ & K.:B & $\mathbf{S}: \mathbf{d}$ & qua" & $\pi x$ & & है & $2 x:$ & $\vdots$ & 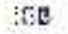 & $2: 3$ \\
\hline & & \multicolumn{2}{|c|}{ It.jt } & & ate.e & & & 128 & & Hises & 30513 \\
\hline & $k$ & ;3:Elad & x: & & & & & & & & \\
\hline
\end{tabular}

\section{Gambar 8. Tampilan Lapoan Penyusutan}


Tampilan Laporan Penyusutan ini berisi tampilan jumlah kelompok aset dan jumlah proses yang dapat mencari laporan lengkapnya di tombol cari laporan.

8. Tampilan menu user

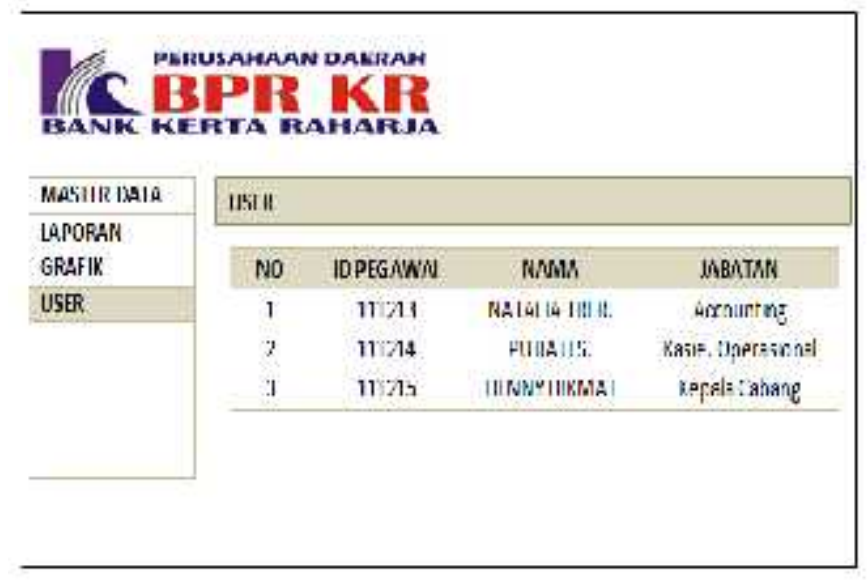

Gambar 9. Tampilan Menu User

Tampilan Menu User ini berisi tentang semua data user yang ada di dalam sistem dan hanya direktur yang dapat melakukan penambahan atau penghapusan user.

\section{KESIMPULAN}

Sistem manajemen aset di PD. BPR Kerta Raharja Cabang Balaraja masih kurang maksimal karena masih dilakukan secara semi komputer dengan menggunakan Microsoft Excel, data belum terdatabase dan belum terintegrasi. Dimana admin juga masih harus menambah baris pada lembar kerja Microsoft Excel untuk dapat menginput apabila ada tambahan aset dan inventaris aset.. Sistem manajemen aset yang berjalan pada PD. BPR Kerta Raharja Cabang Balaraja belum mampu menciptakan laporan dengan cepat dan akurat karena laporan masih mengggunaan aplikasi Ms. Excel. Dimana masih dapat terjadi salah input data aset dan bisa saja data hilang dari penyimpanan. Dari analisa pada sistem manajemen aset yang berjalan di PD. BPR Kerta Raharja Cabang Balaraja, sistem masih cukup lambat sehingga diperlukan adanya sebuah perancangan sistem yang memudahkan user untuk mengakses data aset agar sistem efektif dan efisien.

\section{DAFTAR PUSTAKA}

[1] Kurniawan, Helmi. Fitrianto Rahmad, Iwan. 2012. "Perancangan Sistem Pakar Untuk Mendeteksi Penyakit pada Tanaman Cabe Dengan Metode Certainty Factor". Jurnal CCIT Vol.5 No.2. Tangerang: Perguruan Tinggi Raharja.

[2] Suprihadi, Rini Kartika Hudiono, Lina Sinatra Wijaya. 2013. "Rancangan Bangun Sistem Jejaring Klaster Berbasis Web Menggunakan Metode Model View Controller”. Jurnal CCIT Vol.6 No.3-Mei 2013. Tangerang: Perguruan Tinggi Raharja Raharja [3] Taufiq, Rohmat.2013. Sistem Informasi Manajemen. Yogyakarta: Graha ilmu. 
[4] Simbolon, Junior Remon Afandi. 2017. "Perancangan Sistem Informasi Inventarisasi Aset Tetap pada PT Tirta Nusa Indotama Tangerang”. Skripsi. Tangerang: STMIK Raharja.

[5] Yunitarini, Rika. 2014. "Sistem Informasi Manajemen Tata Kelola Aset Informasi Perhotelan pada Hotel Mahkota Lamongan”. Yogyakarta: Universitas Atmajaya Yogyakarta.

[6] Tri Mardiani, Gentisya. 2013. "Sistem Monitoring Data Aset dan Inventaris PT Telkom Cianjur Berbasis Web”. Bandung: Universitas Komputer Indonesia.

[7] Fauziati, Elmi. 2016. "Perancangan Sistem Infromasi Manajemen Aset Di Kecamatan Pasar Kemis”. Skripsi. Tangerang : STMIK Raharja 